\title{
Oxygen free radical scavengers protect rat islet cells from damage by cytokines
}

\author{
W. Sumoski, H. Baquerizo and A. Rabinovitch \\ Department of Medicine, University of Alberta, Edmonton, Alberta, Canada
}

\begin{abstract}
Summary. A possible role for oxygen free radicals in mediating the cytotoxic effects of cytokines in islets was sought by the use of agents that scavenge free radicals. Rat islet cell monolayer cultures were incubated for 6 days with t-butylhydroperoxide, alloxan, streptozotocin, or the cytokines, interleukin 1, tumour necrosis factor, and interferon gamma, without and together with the oxygen free radical scavenger combination of dimethylthiourea and citiolone, and islet cell lysis was measured in a ${ }^{51}$ chromium cytotoxicity assay. The free radical scavengers significantly inhibited the islet cell cytotoxic effects of t-butylhydroperoxide and alloxan, but not streptozotocin. Similarly, the cytotoxic effects of the cytokine combinations of interleukin 1 plus tumour necrosis factor, in-
\end{abstract}

terferon gamma plus tumour necrosis factor, and interferon gamma plus interleukin 1 were significantly inhibited by the free radical scavenger combination of dimethylthiourea and citiolone. These results suggest that the cytokine products of macrophages and lymphocytes infiltrating islets in Type 1 (insulin-dependent) diabetes may contribute to B-cell damage by inducing the production of oxygen free radicals in the islet cells.

Key words: Islet cells, cytotoxicity, oxygen free radicals, interleukin 1, tumour necrosis factor, interferon gamma, alloxan, streptozotocin.
There is increasing evidence that pancreatic islet B-cell destruction in Type 1 (insulin-dependent) diabetes mellitus is the consequence of immune/inflammatory cellmediated processes, both in human subjects $[1,2]$, and in rodent models with spontaneous Type 1 diabetes [3-7]. A variety of mononuclear cells (T lymphocytes, macrophages, and natural killer cells) have been implicated in islet B-cell destruction in these studies. Whereas it is not known what may elicit the appearance of immune/inflammatory mononuclear cells in islets, their destructive effects may result from direct contact with islet B-cells and/or from secretion of inflammatory products (proteases and free radicals) and immunomodulatory peptides (cytokines).

Recently, it has been demonstrated by several groups [8-16] that the cytokines, interleukin 1 (IL-1), tumour necrosis factor (TNF), and interferon gamma (IFN- $\gamma$ ), acting either alone or more potently in combination, can impair insulin secretion and may be cytotoxic to islet cells in vitro. The cellular and molecular mechanisms responsible for mediating the effects of cytokines on islet B-cells, however, are unknown.

Among the various mechanisms proposed for cell killing by cytokines and other cytotoxic molecules, generation of oxygen free radicals in the target cell has been implicated [17]. Such a mechanism for cytokinemediated islet cell injury was first suggested by Mandrup-Poulsen et al. [18], and is based on the observations that islet cells possess very low oxygen free radical scavenging enzyme activities [19, 20], and are exquisitely vulnerable to free radicals [20]. In the present report, we demonstrate that the oxygen free radical scavengers, dimethylthiourea and citiolone, can significantly protect islet cell monolayer cultures from lysis by the oxygen free radical generators, t-butylhydroperoxide and alloxan, as well as by toxic combinations of the cytokines, IL-1, TNF, and IFN- $\gamma$.

\section{Materials and methods}

\section{Islet cell monolayer cultures}

Islets were isolated from the pancreases of adult Sprague Dawley rats (Biosciences Animal Services, University of Alberta, Edmonton, $\mathrm{AB}$ Canada) and dissociated into single cells by methods previously described [15]. The islet cells were suspended at $0.4 \times 10^{6} / \mathrm{ml}$ in RPMI 1640 medium (Gibco, Grand Island, NY, USA) containing 
Table 1. Effects of oxygen free radical scavengers on rat islet lysis by tert-butylhydroperoxide (t-BHP)

\begin{tabular}{|c|c|c|c|c|}
\hline \multicolumn{2}{|l|}{ Scavenger } & \multicolumn{3}{|l|}{ Islet cell lysis } \\
\hline $\begin{array}{l}\text { Citiolone } \\
(\mathrm{mmol} / \mathrm{l})\end{array}$ & $\begin{array}{l}\text { DMTU } \\
(\mathrm{mmol} / \mathrm{l})\end{array}$ & ${ }^{51} \mathrm{Cr}$ release & $\begin{array}{l}\% \text { Inhibition } \\
\text { by scavenger }\end{array}$ & $p$ \\
\hline 0 & 0 & $46.5 \pm 3.0$ & - & NS \\
\hline 0 & 1 & $42.3 \pm 2.4$ & $8.9 \pm 1.5$ & NS \\
\hline 0 & 3 & $38.5 \pm 3.4$ & $17.2 \pm 4.7$ & NS \\
\hline 0 & 10 & $33.4 \pm 4.1$ & $28.6 \pm 5.0$ & $<0.05$ \\
\hline 1 & 0 & $39.2 \pm 4.5$ & $15.6 \pm 4.2$ & NS \\
\hline 1 & 1 & $26.6 \pm 0.8$ & $42.3 \pm 5.7$ & $<0.01$ \\
\hline 1 & 3 & $22.1 \pm 2.1$ & $52.7 \pm 3.6$ & $<0.001$ \\
\hline 1 & 10 & $25.5 \pm 2.6$ & $45.2 \pm 5.6$ & $<0.01$ \\
\hline 3 & 0 & $33.2 \pm 2.6$ & $33.3 \pm 6.4$ & $<0.05$ \\
\hline 3 & 1 & $19.3 \pm 2.0$ & $58.5 \pm 4.4$ & $<0.001$ \\
\hline 3 & 3 & $21.3 \pm 4.4$ & $54.1 \pm 5.7$ & $<0.01$ \\
\hline 3 & 10 & $22.5 \pm 4.7$ & $50.8 \pm 5.5$ & $<0.01$ \\
\hline
\end{tabular}

Islet cell cultures were incubated in medium containing $0.15 \mathrm{mmol} / 1$ t-BHP, without and with the oxygen free radical scavengers, citiolone and/or dimethylthiourea (DMTU) in the concentrations shown. Islet cell lysis was measured as $\%{ }^{51} \mathrm{Cr}$ release from prelabelled islet cultures after 6 days of incubation. Values are means \pm SEM for 4-5 experiments. The $\%$ inhibition of t-BHP-induced islet cell lysis was determined in each experiment and is shown together with the statistical significances $(p)$ of the differences between islet cell lysis by $t-$ BHP in the absence and the presence of scavengers, using the paired Student's $t$-test

Table 2. Effects of oxygen free radical scavengers on rat islet cell lysis by different cytotoxins

\begin{tabular}{llccl}
\hline $\begin{array}{l}\text { Cytotoxin } \\
\text { (mmol/1) }\end{array}$ & & \multicolumn{2}{l}{ Islet cell lysis } & \\
\cline { 3 - 5 } & & $\begin{array}{l}\text { Without scavengers } \\
\left(\%{ }^{51} \text { Cr release }\right)\end{array}$ & $\begin{array}{c}\text { With scavengers } \\
\left(\%^{51} \text { Cr release }\right)\end{array}$ & $p$ \\
\hline t-BHP & 0.05 & $1.4 \pm 0.5$ & $2.2 \pm 0.8$ & NS \\
& 0.10 & $19.6 \pm 5.8$ & $6.0 \pm 1.2$ & $<0.05$ \\
& 0.15 & $47.3 \pm 8.8$ & $20.3 \pm 5.6$ & $<0.01$ \\
& 0.20 & $67.3 \pm 6.3$ & $52.1 \pm 4.8$ & $<0.05$ \\
Alloxan & 2.0 & $5.9 \pm 1.9$ & $9.0 \pm 2.2$ & NS \\
& 2.5 & $17.1 \pm 6.0$ & $19.1 \pm 2.9$ & NS \\
& 3.0 & $44.7 \pm 2.3$ & $30.6 \pm 2.3$ & $<0.01$ \\
& 3.5 & $63.4 \pm 9.0$ & $37.7 \pm 7.7$ & $<0.05$ \\
Strepto- & 0.05 & $4.2 \pm 2.5$ & $6.8 \pm 4.6$ & NS \\
zotocin & 0.10 & $34.7 \pm 9.4$ & $26.8 \pm 9.0$ & NS \\
& 0.15 & $72.6 \pm 8.1$ & $70.5 \pm 3.5$ & NS \\
& 0.20 & $79.7 \pm 5.3$ & $79.9 \pm 5.6$ & NS \\
\hline
\end{tabular}

Islet cell cultures were incubated in medium containing the cytotoxins shown, without and with the free radical scavenger combination of $1 \mathrm{mmol} / 1$ dimethylthiourea and $3 \mathrm{mmol} / 1$ citiolone. Islet cell lysis was measured as $\%{ }^{51} \mathrm{Cr}$ release from prelabelled islet cultures after 6 days of incubation. Values are means \pm SEM for 4-5 experiments. Statistical significances $(p)$ are shown for the differences between islet cell lysis by each cytotoxin in the absence and the presence of scavengers, using the paired Student's $t$-test. $\mathrm{t}-\mathrm{BHP}=$ tert-butylhydroperoxide

$11 \mathrm{mmol} / 1$ glucose, $100 \mathrm{U} / \mathrm{ml}$ penicillin, $100 \mu \mathrm{g} / \mathrm{ml}$ streptomycin, $20 \mu \mathrm{g} / \mathrm{ml}$ amphotericin B, $12 \mathrm{mmol} / 1 \mathrm{HEPES}$, and $10 \%$ heat-inactivated fetal calf serum (complete medium). To promote islet cell reaggregation and monolayer formation, $0.1 \mathrm{mmol} / 1$ 3-isobutyl-1methylxanthine (IBMX) was added to the medium [15]. The cells were seeded in this medium $\left(4 \times 10^{4} /\right.$ well) in 96-well half-area microculture plates (Costar, Cambridge, Mass., USA), and incubated in a humidified incubator at $37^{\circ} \mathrm{C}$ in $95 \%$ air $/ 5 \% \mathrm{CO}_{2}$. After 5-7 days, the islet cells had reaggregated in small clusters of
$10-100$ cells attached to the bottom of the wells and spread out in monolayer. The cultures were then washed and reincubated in complete medium (without IBMX) for 3 days.

\section{Islet cell cytotoxicity assay}

Islet cell monolayer cultures were labelled by incubation for $24 \mathrm{~h}$ at $37^{\circ} \mathrm{C}$ with $1 \mu \mathrm{Ci}{ }^{51} \mathrm{Cr}$ sodium chromate (New England Nuclear, Boston, Mass., USA) in $170 \mu 1$ complete medium per well, then washed 4 times, reincubated for $96 \mathrm{~h}$ in ${ }^{51} \mathrm{Cr}$-free complete medium, and washed again 4 times. Test agents (t-butylhydroperoxide, alloxan, streptozotocin, cytokines) were added to the monolayers in the absence and presence of the free radical scavengers, dimethylthiourea and citiolone $(170 \mu \mathrm{V} /$ well in quadruplicate) and the plates were incubated at $37^{\circ} \mathrm{C}$ for 6 days. An aliquot $(100 \mu \mathrm{l})$ of supernatant medium was collected from each well and counted in a gamma counter. Percent specific cell lysis was calculated as $100 \% \times$ (test medium cpmspontaneous $\mathrm{cpm}) /($ total $\mathrm{cpm}-$ spontaneous $\mathrm{cpm}$ ). Spontaneous release of ${ }^{51} \mathrm{Cr}$ was measured in wells incubated in medium alone and this was $<12 \%$ of total ${ }^{51} \mathrm{Cr}$ release, measured by dissolving the cells in $4 \%$ Triton $X-100$ for $16 \mathrm{~h}$.

\section{Cytokines and chemicals}

Recombinant (r) human TNF- $\alpha\left(4 \times 10^{7} \mathrm{U} / \mathrm{mg}\right)$ was kindly provided by J. Kaumeyer (Genentech, San Francisco, Calif., USA), r human IL$1-\beta\left(10^{8} \mathrm{U} / \mathrm{mg}\right)$ was purchased from Genzynne (Boston, Mass., USA), and $r$ rat IFN- $\gamma\left(4 \times 10^{6} \mathrm{U} / \mathrm{mg}\right)$ was purchased from Amgen Biologicals (Thousand Oaks, Calif., USA). Alloxan (Sigma, St. Louis, Mo, USA), and streptozotocin (STZ) (Upjohn, Kalamazoo, Mich., USA) were dissolved in citrate buffer ( $\mathrm{pH} 4.6)$ as $0.5 \mathrm{~mol} / 1$ stock solutions and diluted in complete medium immediately before use. Tertbutylhydroperoxide (t-BH[P), and $\mathrm{N}$-acetyl-homocysteine-thiolactone (citiolone) were purchased from Sigma, and dimethylthiourea (DMTU) from Aldrich (Milwaukee, Wis., USA). Stock solutions of DMTU $(1 \mathrm{~mol} / \mathrm{l})$ citiolone $(0.5 \mathrm{~mol} / 1)$, and t-BHP $(0.1 \mathrm{~mol} / \mathrm{l})$ were freshly prepared in distilled water and diluted in complete medium immediately before use.

\section{Statistical analysis}

Data are presented as mean values \pm SEM, and statistical analysis was done with Student's two-tailed $t$-test for paired data.

\section{Results}

\section{Free radical scavengers protect against $t-B H P$ and alloxan}

The islet cell cytotoxic action of the oxygen free radical generator, t-BHP was inhibited in a dose-dependent fashion by either of the two oxygen free radical scavengers, DMTU or citiolone, and combination of the two scavengers produced additive effects (Table 1). Thus, $0.15 \mathrm{mmol} / 1 \mathrm{t}$-BHP produced $46.5 \pm 3.0 \%$ lysis of islet cells, and this was decreased by $28.6 \pm 5.0 \%(p<0.05)$ by $10 \mathrm{mmol} / 1$ DMTU, $33.3 \pm 6.4 \% \quad(p<0.05)$ by $3 \mathrm{mmol} / \mathrm{l}$ citiolone, and by $50.8 \pm 5.5 \%(p<0.01)$ by the 

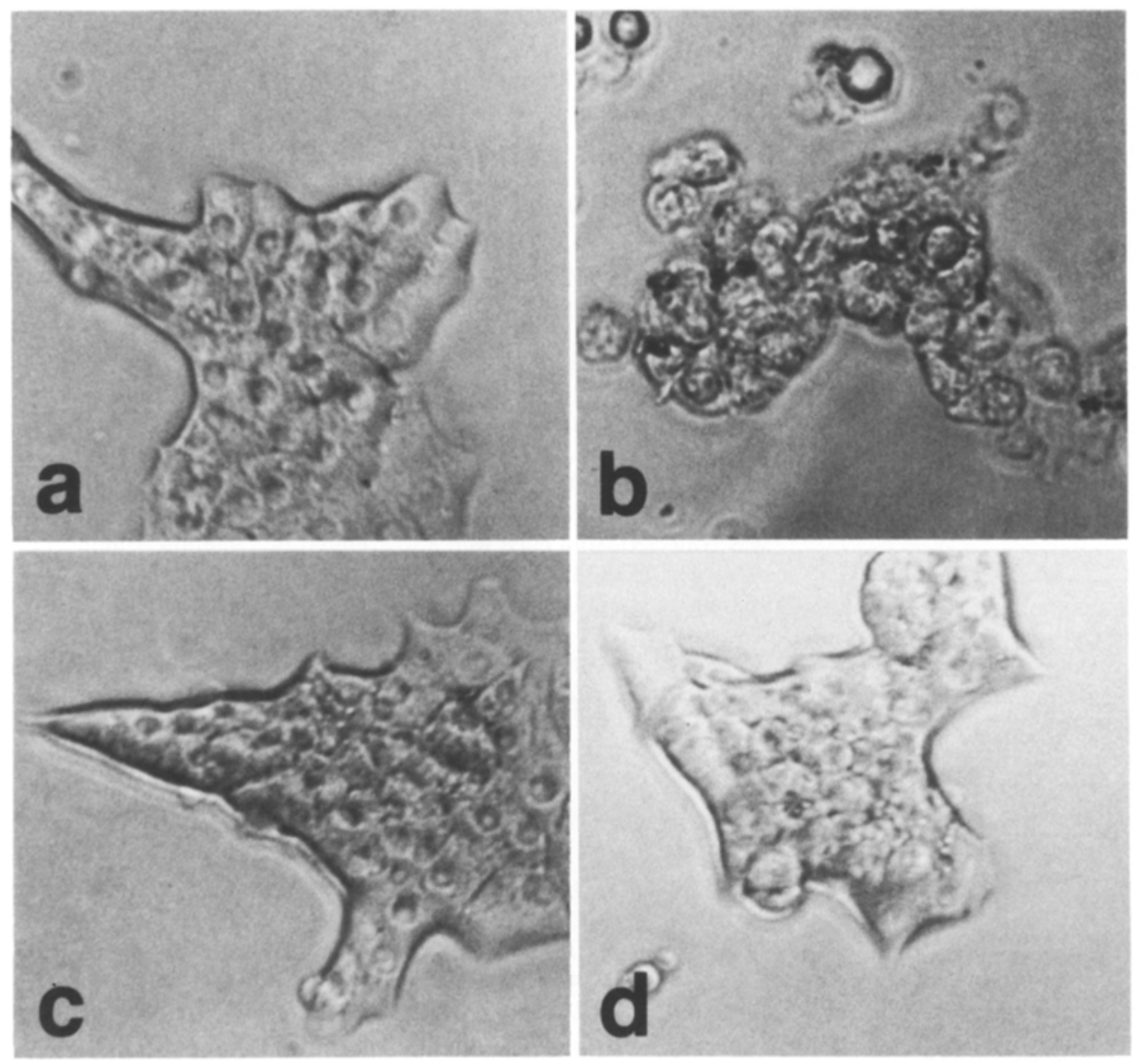

Fig.1 a-d. Phase contrast photomicrographs (x250) of rat islet cells in monolayer culture after incubation for 6 days in RPMI-1640 complete medium (control, a) and the same medium with further supplements (b-d). The combination of interferon gamma (IFN- $\gamma)(10 \mathrm{U} / \mathrm{ml})$ and tumour necrosis factor (TNF) $\left(10^{3} \mathrm{U} / \mathrm{ml}\right)$ caused islet cell necrosis (b). Dimethylthiourea (DMTU) $(1 \mathrm{mmol} / \mathrm{l})$ together with citiolone ( $3 \mathrm{mmol} / \mathrm{l}$ ) did not affect the islet cells (c). The addition of DMTU and citiolone to TNF plus IFN- $\gamma$ protected the islet cells from the toxic effects of the cytokines (compare $\mathbf{d}$ and $\mathbf{b}$ ) combination of $10 \mathrm{mmol} / 1 \mathrm{DMTU}$ and $3 \mathrm{mmol} / 1$ citiolone. The strongest inhibition of the cytotoxic effect of $\mathrm{t}$-BHP was obtained with the combination of $1 \mathrm{mmol} / \mathrm{l}$ DMTU and $3 \mathrm{mmol} / 1$ citiolone $(58.5 \pm 4.4 \%$ inhibition, $p<0.001)$. Therefore, this combination of concentrations of DMTU $(1 \mathrm{mmol} / \mathrm{l})$ and citiolone $(3 \mathrm{mmol} / \mathrm{l})$ was used in subsequent experiments.

In addition to inhibiting the islet cytotoxic effect of t-BHP, the free radical scavenger combination of DMTU and citiolone also protected against the cytotoxicity of the islet B-cell toxin, alloxan, but not streptozotocin (Table 2). The greatest protection by the free radical scavengers occurred at intermediate levels of islet cell lysis $\left(30-50 \%{ }^{51} \mathrm{Cr}\right.$ release) produced by either t-BHP or alloxan $(p<0.01)$. In contrast, the free radical scavengers did not provide significant protection against streptozotocin-induced islet cell lysis.

\section{Free radical scavengers protect against cytokines}

The free radical scavenger combination of $1 \mathrm{mmol} / 1$ DMTU and $3 \mathrm{mmol} / 1$ citiolone was then tested in incubations with cytokines (Table 3$)$. IL-1 $(1.0 \mathrm{U} / \mathrm{ml})$, IFN$\gamma(10 \mathrm{U} / \mathrm{ml})$, and TNF $\left(10^{3} \mathrm{U} / \mathrm{ml}\right)$ were not cytotoxic as single agents, however, combinations of IL-1 and TNF, IFN- $\gamma$ and TNF, and IFN- $\gamma$ and IL-1 exerted dose-dependent cytotoxic effects, as we have reported pre- viously [15]. These cytokine-induced lytic effects were inhibited by the free radical scavenger combination of DMTU and citiolone, and the greatest protection against islet cell lysis occurred at intermediate levels of cytotoxicity (30-45\% ${ }^{51} \mathrm{Cr}$ release) delivered by any of the cytokine combinations. The free radical scavengers were more protective against combinations of IFN- $\gamma$ and TNF $(50-60 \%$ inhibition, $p<0.01)$ than against combinations containing IL-1 (IL-1 plus TNF, and IFN- $\gamma$ plus IL-1) (20-35\% inhibition, $p<0.05-0.01)$. The protective effect of DMTU and citiolone against IFN- $\gamma$ plus TNF-mediated lysis of the islet cell monolayers was also evident by phase contrast microscopy (Fig.1).

\section{Discussion}

We have previously reported that the cytotoxic effects of cytokines on islet cells can be monitored and quantitated in a ${ }^{51} \mathrm{Cr}$ release cytotoxicity assay using rat islet cells in monolayer culture [15]. In the present study, we have used this assay to investigate a possible role for oxygen free radicals in mediating the cytolytic effects of cytokines on islet cells, since cytokines are known to induce free radical generation in other cell types [17]. 
Table 3. Effects of oxygen free radical scavengers on rat islet cell lysis by different cytokine combinations

\begin{tabular}{|c|c|c|c|}
\hline \multirow{2}{*}{$\begin{array}{l}\text { Cytokine } \\
(\mathrm{U} / \mathrm{ml})\end{array}$} & \multicolumn{3}{|l|}{ Islet cell lysis } \\
\hline & $\begin{array}{l}\text { Without scavengers } \\
\left(\%{ }^{51} \mathrm{Cr} \text { release) }\right.\end{array}$ & $\begin{array}{l}\text { With scavengers } \\
\left(\%{ }^{51} \mathrm{Cr} \text { release }\right)\end{array}$ & $p$ \\
\hline IL-1 1.0 & $4.5 \pm 1.0$ & $5.3 \pm 1.5$ & NS \\
\hline IL-1 $1.0+$ TNF 10 & $9.0 \pm 2,6$ & $7.8 \pm 2.5$ & NS \\
\hline IL-1 $1.0+$ TNF $10^{2}$ & $17.5 \pm 2.5$ & $10.4 \pm 3.0$ & $<0.05$ \\
\hline IL- $1 \quad 1.0+$ TNF $10^{3}$ & $30.7 \pm 2.7$ & $20.7 \pm 2.4$ & $<0.01$ \\
\hline IFN- $\gamma 10$ & $5.9 \pm 1.2$ & $2.6 \pm 1.2$ & NS \\
\hline IFN- $\gamma 10+$ TNF 10 & $9.9 \pm 2.7$ & $4.8 \pm 2.0$ & $<0.05$ \\
\hline IFN- $\gamma 10+$ TNF $10^{2}$ & $33.2 \pm 5.0$ & $14.4 \pm 3.1$ & $<0.01$ \\
\hline 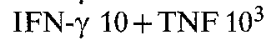 & $43.2 \pm 6.7$ & $21.7 \pm 4.0$ & $<0.01$ \\
\hline TNF $10^{3}$ & $1.9 \pm 0.6$ & $3.1 \pm 1.0$ & NS \\
\hline IFN- $\gamma 10+$ IL-1 0.1 & $31.4 \pm 3.1$ & $20.5 \pm 4.0$ & $<0.05$ \\
\hline IFN- $\gamma 10+$ IL-1 1 & $42.8 \pm 3.9$ & $33.7 \pm 4.3$ & $<0.05$ \\
\hline IFN- $\gamma 10+$ IL-1 10 & $45.7 \pm 3.8$ & $43.8 \pm 3.5$ & NS \\
\hline
\end{tabular}

Islet cell cultures were incubated in medium containing the cytokines shown, without and with the free radical scavenger combination of $1 \mathrm{mmol} / 1$ dimethylthiourea and $3 \mathrm{mmol} / 1$ citiolone. Islet cell lysis was measured as ${ }^{51} \mathrm{Cr}$ release from prelabelled islet cultures after 6 days of incubation. Values are means \pm SEM for 4-6 experiments. Statistical significances $(p)$ are shown for the differences between islet cell lysis by each cytokine or cytokine combination in the absence and the presence of scavengers, using the paired Student's $t$-test. IL- $1=$ interleukin $1 ; \mathrm{TNF}=$ tumour necrosis factor; IFN $-\gamma=$ interferon gamma

First, we identified oxygen free radical scavengers which significantly inhibited the cytotoxic effect of known free radical generators, the non-specific cytotoxin, t-BHP, and the islet B-cell specific toxin, alloxan. We showed that both t-BHP and alloxan are highly toxic to islet cells, and that this toxicity can be significantly inhibited by the combination of two free radical scavengers, DMTU and citiolone. DMTU and citiolone are scavengers of hydroxyl free radicals $\left({ }^{\circ} \mathrm{OH}\right)$, considered as the most reactive and damaging of the oxygen-derived free radicals. In addition to scavenging of ' $\mathrm{OH}$ [21], citiolone has the ability to increase superoxide dismutase (SOD) activity in rat islets [22]. SOD catalyses the conversion of superoxide radicals $\left(\mathrm{O}_{2}^{--}\right)$to hydrogen peroxide $\left(\mathrm{H}_{2} \mathrm{O}_{2}\right)$, thereby decreasing the amounts of $\mathrm{O}_{2}{ }^{-}$available to form ${ }^{\circ} \mathrm{OH}$. Thus, DMTU and citiolone would be expected to have additive effects in protecting against free radical-induced cell injury, as we observed using this combination of scavengers to counter the cytotoxic effects of the oxygen free radical generator, t-BHP.

Interestingly, the free radical scavenging combination of DMTU and citiolone significantly inhibited the islet cell cytotoxic effect of alloxan and not streptozotocin. It is well established that both alloxan and streptozotocin are selective B-cell toxins, however the mechanisms that impart their selective toxicity remain controversial. There is evidence that alloxan and streptozotocin may act to kill B-cells by different mechanisms [23]. Our findings that the free radical scavengers inhibited alloxan and not streptozotocin-induced islet cell killing are in agreement with other studies which suggest that alloxan acts through generation of hydroxyl radicals whereas streptozotocin may act via other mechanisms [24, 25].

Since the free radical scavenging combination of DMTU and citiolone significantly inhibited the cytotoxic effects of the free radical generators, t-BHP and alloxan and also significantly inhibited the cytotoxic effects of cytokine combinations (TNF+IL-1, IFN$\gamma+\mathrm{TNF}$, and IFN- $\gamma+$ IL-1), it follows that these cytokine combinations may be toxic by leading to the formation of oxygen free radicals in islet cells. An oxygen free radical-mediated mechanism for cytokineinduced islet cell injury is compatible with the report by Eizirik that IL-1/TNF-induced islet cell toxicity is associated with inhibition of oxidative metabolism of glucose [13], since interference with mitochondrial energy production is recognized as an early manifestation of oxygen free radical-mediated injury [26].

The cytokines, IL-1, TNF, and IFN- $\gamma$ have been reported to stimulate oxygen free radical production during the respiratory burst in a variety of cell types, such as macrophages [27] and polymorphonuclear leukocytes [28] in association with host defense against micro-organisms and tumours. Stimulation of oxygen free radical production in pancreatic islet cells, however, might be expected to have lethal consequences to islet cells since islet cells possess very low free radical scavenging enzyme activities [19, 20], and therefore are exquisitely vulnerable to free radical-induced injury [20]. Cytokine-induced oxygen free radicals are primarily products of arachidonic acid metabolism in many cell types, and we have recently observed that inhibitors of arachidonic acid metabolism can protect islet cells from the cytotoxic effects of TNF and IFN- $\gamma$. It remains to be directly demonstrated, however, that cytokines stimulate increased arachidonate metabolism and free radical production in islet cells.

Evidence exists to suggest involvement of oxygen free radicals in immune-mediated damage to islet B-cells, in vivo. Thus, desferrioxamine, an inhibitor of hydroxyl radical formation, and nicotinamide, a poly (ADP-ribose) synthetase inhibitor and a weak free radical scavenger, protected islet cells from immune destruction in allograft rejection and in low-dose streptozotocin-induced insulitis [29]. Also, treatment of spontaneously diabetic NOD mice with nicotinamide and desferrioxamine [30], or with superoxide dismutase [31], protected islet grafts from immune damage and consequent recurrence of diabetes. Activated macrophages in the insulitis infiltrate [32] might be the source of islet-damaging free radicals, and activated peritoneal macrophages have been reported to be cytotoxic to islet cells [33]. In addition, our findings suggest that the cytokine products of lymphocytes and macrophages in the islet infiltrate might contribute to immune-mediated damage by stimulating the generation of oxygen free radicals in the islet cells. 
Acknowledgements. We gratefully acknowledge the technical assistance of Ms. C.Erickson and the secretarial assistance of Ms. S. Schroeder. This study was funded by the Alberta Heritage Foundation for Medical Research and the Muttart Diabetes Research and Training Centre.

\section{References}

1. Barbosa J, Bach FH (1987) Cell-mediated autoimmunity in Type I diabetes. Diabetes Metab Rev 3: 981-1004

2. Boitard C, Chatenoud LM, Debray-Sachs M (1982) In vitro inhibition of pancreatic $\beta$ cell function by lymphocytes from diabetics with associated autoimmune diseases: a $\mathrm{T}$ cell phenomenon. $\mathrm{J}$ Immunol 129: 2529-2531

3. Charlton BA, Bacelj A, Mandel TE (1988) Administration of silica particles or anti-Lyt 2 antibody prevents beta-cell destruction in NOD mice given cyclophosphamide. Diabetes 37:930-935

4. Wang Y, Hao L, Gill R, Lafferty KJ (1987) Autoimmune diabetes in NOD mouse is L3T4 T-lymphocyte dependent. Diabetes 36: 535-538

5. Like AA, Biron CA, Weringer EJ, Byman K, Sroczynski E, Guberski DL (1986) Prevention of diabetes in BioBreeding/Worcester rats with monoclonal antibodies that recognize $T$ lymphocytes or natural killer cells. J Exp Med 164: 1145-1159

6. Oschilewski U, Kiesel U, Kolb H (1985) Administration of silica prevents diabetes in BB rats. Diabetes 34: 197-199

7. Jacobson JD, Markmann JF, Brayman KL, Barker CF, Naji A (1988) Prevention of recurrent autoimmune diabetes in BB rats by anti asialo GM1 antibody. Diabetes 37: 838-841

8. Mandrup-Poulsen T, Bendtzen K, Nerup J, Dinarello CA, Svenson M, Nielsen JH (1986) Affinity-purified human interleukin 1 is cytotoxic to isolated islets of Langerhans. Diabetologia 29: 63-67

9. Zawalich WS, Diaz VA (1986) Interleukin 1 inhibits insulin secretion from isolated perifused rat islets. Diabetes 35: 1119-1123

10. Comens PG, Wolf BA, Unanue ER, Lacy PE, McDaniel M (1987) Interleukin 1 is potent modulator of insulin secretion from isolated islets of Langerhans. Diabetes 36: 963-970

11. Sandler S, Andersson A, Hellerström C (1987) Inhibitory effects of interleukin 1 on insulin secretion, insulin biosynthesis, and oxidative metabolism of isolated rat pancreatic islets. Endocrinology 121: 1424-1431

12. Eizirik DL, Strandell E, Bendtzen K, Sandlers S (1988) Functional characteristics of rat pancreatic islets maintained in culture following exposure to human interleukin 1 . Diabetes 37: 916-919

13. Eizirik D (1988) Interleukin-1 induced impairment in pancreatic islet oxidative metabolism of glucose is potentiated by tumor necrosis factor. Acta Endocrinol (Copenh) 119: 321-325

14. Mandrup-Poulsen T, Bendtzen K, Dinarello CA, Nerup J (1987) Human tumor necrosis factor potentiates human interleukin 1mediated rat pancreatic $\beta$-cell cytotoxicity. J Immunol 139: 4077-4082

15. Pukel C, Baquerizo H, Rabinovitch A (1988) Destruction of rat islet cell monolayers by cytokines: synergistic interactions of interferon- $\gamma$, tumor necrosis factor, lymphotoxin, and interleukin 1. Diabetes 37: 133-136

16. Campbell IL, Iscaro A, Harrison LC (1988) IFN- $\gamma$ and tumour necrosis factor- $\alpha$. Cytotoxicity to murine islets of Langerhans. J Immunol 141: 2325-2329

17. Ruddle NH (1987) Tumor necrosis factor and related cytotoxins. Immunol Today 8: 129-130

18. Mandrup-Poulsen T, Spinas GA, Prowse SJ, Hansen BS, Jorgensen DW, Bendtzen K, Nielsen JH, Nerup J (1987) Islet cytotox- icity of interleukin 1. Influence of culture conditions and islet donor characteristics. Diabetes 36: 641-647

19. Asayama K, Kooy NW, Burr IM (1986) Effect of vitamin E deficiency and selenium deficiency on insulin secretory reserve and free radical scavenging systems in islets: decrease of islet manganosuperoxide dismutase. J Lab Clin Med 107: 459-464

20. Malaisse WJ, Malaisse-Lagae F, Sener A, Pipeleers DG (1982) Determinants of the selective toxicity of alloxan to the pancreatic B cell. Proc Natl Acad Sci USA 79: 927-930

21. Aloj Totaro E, Pisanti FA, Liberatori E (1985) Possible interrelation of acetyl-homocyteine-thiolactone in mechanisms of lipofuscinogenesis. Res Commun Chem Pathol Pharmacol 47: 415-426

22. Papaccio G, Pisanti FA, Frascatore S (1986) Acetyl-homocysteine-thiolactone-induced increase of superoxide dismutase counteracts the effect of subdiabetogenic doses of streptozocin. Diabetes 35: $470-474$

23. Fischer LJ, Rickert DE (1975) Pancreatic islet-cell toxicity. CRC Crit Rev Toxicol 3: 231-263

24. Wilson GL, Hartig PC, Patton NJ, LeDoux SP (1988) Mechanisms of nitrosourea-induced $\beta$-cell damage. Activation of poly (ADP-ribose) synthetase and cellular distribution. Diabetes 37: 213-216

25. LeDoux SP, Hall CR, Forbes PM, Patton NJ, Wilson G (1988) Mechanisms of nicotinamide and thymidine protection from alloxan and streptozotocin toxicity. Diabetes 37: 1015-1019

26. Autor AP (1984) Oxygen toxicity in eukaryotes. In: Bannister JV, Bannister WH (eds) The biology and chemistry of active oxygen: developments in biochemistry, Vol 26. Elsevier, Amsterdam, pp 139-145

27. Nathan CF, Tsunawaki S (1986) Secretion of toxic oxygen products by macrophages: regulatory cytokines and their effects on the oxidase. Ciba Found Symp 118: 211-230

28. Berton G, Zeni L, Cassatella MA, Rossi F (1986) Gamma interferon is able to enhance the oxidative metabolism of human neutrophils. Biochem Biophys Res Commun 138: 1276-1282

29. Mendola J, Wright JR, Lacy PE (1989) Oxygen free-radical scavengers and immune destruction of murine islets in allograft rejection and multiple low-dose streptozotocin-induced insulitis. Diabetes 38: 379-385

30. Nomikos IN, Prowse SJ, Carotenuto P, Lafferty KJ (1986) Combined treatment with nicotinamide and desferrioxamine prevents islet allograft destruction in NOD mice. Diabetes 35: 1302-1304

31. Nomikos IN, Wang $\mathrm{Y}$, Lafferty $\mathrm{KJ}$ (1989) Involvement of $\mathrm{O}_{2}$ radicals in autoimmune diabetes. Immunol Cell Biol 67: 85-87

32. Hanenberg $\mathrm{H}$, Kolb-Bachofen V, Kantwerk-Funke G, Kolb H (1989) Macrophage infiltration precedes and is a prerequisite for lymphocytic insulitis in pancreatic islets by prediabetic BB rats. Diabetologia 32: 126-134

33. Appels B, Burkart V, Kantwerk-Funke G, Funda J, Kolb-Bachofen V, Kolb H (1989) Spontaneous cytotoxicity of macrophages against pancreatic islet cells. J Immunol 142: 3803-3808

Received: 2 January 1989

and in revised form: 28 July 1989

Dr. A. Rabinovitch

Clinical Sciences Building, Room 8-121

University of Alberta

Edmonton, Alberta T6G 2G3

Canada 